\title{
Chief, Land, and Family
}

This article will demonstrate how the 'mana model' enhances mātauranga (Cuthers, 2018). I will critically discuss three principles that guide my practice; chief, land and family. I will discuss and compare relevant work from three sources on each of these principles that underlie my practice. In this article, I will utilise autoethnography and discuss the story of my tupuna to encourage others to embrace their identity and enhance their mana. In researching aspects of my history and mātauranga that are directly linked to my whakapapa, I am hereditarily entangled in this literature (Rangiwai, 2018).

The role of a chief, according to Tomoniko (2014), is to provide cohesion to a community and to enable it to function correctly. I agree that a chief is a leader that binds the people and the land together for the betterment of the collective. Tomoniko's perspective is of a chief's role that has been tested over time by outside influences. However, Tomoniko maintains that the role of a chief has withstood the test of time and remained the same. I agree; despite Western influences such as Christianity and globalisation, the chief's role has always been to unite his or her people and to provide a means for them to function on their land.

In Rarotonga, there are six paramount chiefs: Makea, Karika, Vakātini, Pā, Kainuku, and Tinomana. I will focus my discourse on the family of Tinomana, the first title holder of which was Motoro, son of Tangi'ia, the captain of the Tākitumu vaka (Holmes and Crocombe, 2014). The story of Tinomana is one of my narratives. "Our stories are our history and are an important component of identity that should be treated as a taonga" (Cuthers, 2018, p. 367). Retelling the stories of our 
chiefs and our tupuna enhances mātauranga of self which, in turn, develops a greater understanding of the world around us. Gear (2018) believes that the understanding of self is first needed before we can understand the world. From first-hand experience I find Gear's belief to be true. I connect with Tinomana through my maternal whakapapa and in retelling his story I have come to better understand myself. I have the power to view the world through his eyes and erase the time and space between us. Spiller and Wolfgramm (2015) agree with the concept of eradication of time and space and suggest that "whakapapa is the continuum of life that actively brings ancestors and future generations together in the present" ( $\mathrm{p}$. 285). Stories held within whakapapa allow me to accumulate mātauranga without the restriction of time. It allows Tinomana to transmit mātauranga to me. Rangiwai (2018) agrees that in seeking out our stories, we re-discover our mātauranga.

Tinomana is the traditional guardian of the people and land of the Pua'ikura district in Rarotonga. Tomoniko (2014) explains that the role of the chief is to be the guardian and protector of people. Tomoniko furthermore argues that the chief is also the guardian and protector of tradition, which I agree with. However, I argue that a chief is not only a protector of heritage but also a symbol of heritage, a symbol of the oral tradition of the family. Swidler, Dongoske, Anyon and Downer (1997) believe that oral traditions incorporate the knowledge of ancestors. Therefore, the chief is a symbol of the family knowledge. Tinomana embodies the knowledge of my tupuna and also contributes to contemporary knowledge. "The word whakapapa refers to the layering of knowledge, one order upon another". (Spiller and Wolfgramm, 2015, p. 285). Each tupuna from Tinomana to me is significant and leaves their chapter in the book of mattauranga that is the whakapapa. The voices of my tupuna speak and transcend time through their stories. Their stories teach me and reflecting on these stories enhances my mātauranga of self and strengthens my mana. Rangiwai (2018) explains that our literature is embedded in our world, in 
the land and the sea where we find our stories, our knowledge. Treasuring our chief and tupuna maintains our heritage and traditions and therefore protects our mātauranga. We keep our tupuna and our knowledge alive through retelling our stories. Death does not separate the dead from the living.

The stories embodied by our chiefs and tupuna contribute to both our historical and contemporary mātauranga. Hau'ofa (2000) agrees that our chiefs are our history explaining that "most of our ancient and even our more recent oral histories are about the lives and heroic and horrific deeds of our great chiefs" (p. 463). Our culture and identity have been developed based on our oral histories, our stories. I agree with Hau'ofa that our knowledge derives from the actions of our chiefs and tupuna. He explains, "Our histories, cultures, and group identities are focused almost entirely on them" (p. 463). Their actions, whether right or wrong, contribute to who we are because we can learn not only from their achievements but also from the lessons of their failures. Our chiefs are the foundation of families, the foundation of relationships with the environment and also the origin of our mātauranga.

The title Tinomana was passed down to Enuarurutini who was chief in the 1820s. His actions as Tinomana transformed our contemporary mātauranga. His name, meaning 'land and people combined' which Jonassen (2003) believes refers to a united land of many people, symbolises unity. Enuarurutini was named to unite his people, and his land and his name symbolises part of our history and demonstrates the interconnectedness between the chief, family and land (Cuthers, 2018). Jonassen (2003) agrees that names not only remind us of responsibilities to our ancestors but also of our responsibilities to our descendants. My tupuna was prophetically named to unite the people and the land, not just in his time but throughout the generations.

Despite belonging to the land of Pua'ikura, Tinomana Enuarurutini was born and raised in the mountains where the Tinomana family resided at the time (William, 1842). The 
Tinomana family had been continually plundered by other districts and were driven from their land to seek refuge inland in the mountains. There, they suffered under the oppression of more powerful families and were unable to utilize and connect with their land (Gilson, 1980). According to Gilbert (2016) "land is life" (p. 173). However, the Tinomana family was vulnerable to the attacks because they were displaced from their lands. They were weakened and remained besieged and under genuine threat of extinction until rescued by the arrival of Christianity in the form of one of the first missionaries to reside in the Cook Islands, Papeiha (Holmes and Crocombe, 2014). Papeiha was a Society Islander who had volunteered to go to Rarotonga in 1823 (Glison, 1980). Tinomana chose to accept Christianity that year, and as a consequence, the Tinomana family were able to descend from the hills and return to their lands under the protection of the missionaries (Gilson, 1980).

According to Gilbert (2016), "there is a connection between indigenous people's right to use their land and their survival, as without access to their land, indigenous communities would not access their means of livelihood" (p. 173). I agree with Gilbert and believe that while they were living in the hills, without access to their lands, the Tinomana family was in jeopardy of losing their future. However, Tinomana knew the importance of their land to sustain them, and as a consequence of his actions as chief of his people, they reclaimed their land, and I believe the sense of belonging and identity that came with it. Wilson (2008) argues that the ground and environment from which indigenous people come is what makes them. I somewhat agree with Wilson. However, I believe that the ground and environment contributes to who indigenous people are rather than makes them who they are. I was born in Aotearoa, and although I belong to land in Rarotonga, this land did not entirely make me who I am today. It is part of my identity and has contributed to who I am. I have come to understand the importance of this land. However, I believe it did not solely make me. Due to globalisation, I was disconnected from my land for 
most of my life. Now that I have reconnected with my land I believe it is essential to understand our relationship to the land and how it contributes to our identity.

Dagar (2014) agrees that land is a source of identity and, moreover, a way of life. We have connectivity to land; we bury our people on our land, our stories of creation originate from our land. The land shapes our roles. I believe that understanding our relationships with land enables mātauranga. Wilson (2008) agrees with my view of land as a foundation for knowledge explaining that "knowledge itself is held in the relationships and connections formed with the environment that surrounds us" (p. 87). Our history with the land reveals a narrative that contributes to our contemporary identity. These stories can also tell accounts of disconnection such as the story of Tinomana. These are not merely stories that tell of harmonious relationships with the land. In contrast, I believe that stories of not being able to access the land that we once belonged to contributes just as much to our contemporary identity.

Our history and our land are intertwined. Our land enhances our mana; the more land we have, the more mana we have. Dagar (2014) agrees and suggests that land is a source of status. While Tinomana remained confined to the mountains, his people had little access to plantations or the ocean. Consequently, at that time, Tinomana was chief of little mana. However, in reclaiming a meaningful relationship with the land for his people Tinomana achieved great mana. Christianity enabled Tinomana to extend his powers (Holmes and Crocombe, 2014). He extended his reach, and his family grew strong along with the mana in the Tinomana title. This validates Dagar's argument that land is a source of status. Larmour and Alatoa (1984) agree that if a man does not control land, he has no status or power. Tinomana and his family reclaimed their mana which was constructed through their relationship to their land. Wilson (2008) agrees with this view and says "the land is paramount for all indigenous societies. Their relationship to 
that land, their experience on that land shapes everything that is around them" (p. 87). I agree with Wilson and believe that land not only shapes everything around them, it also contributes to who they are.

Tinomana Enuarurutini lived up to his name and fulfilled his role as guardian over his people and land. Tinomana was the paramount chief of Pua'ikura, all the land belonged to Tinomana and all the people on the land belonged to his family. Meleisea (1987) agrees with this notion of guardianship by reaffirming that a chief is the custodian of the property of their family and has the mana to allocate land and other resources. This view supports the interconnectedness of chief, family and land. Tomoniko (2014) agrees that the leadership of the chief is bound within their own families and connected to a physical land.

Enuarurutini had four wives, one of whom was Te Pori, the daughter of Pā Taputaputatea the paramount chief of Tākitumu. Their eldest daughter of many children was Te vaerua o te rangi. Te vaerua o te rangi was married to Papeiha, which strengthened the relationship between the Tinomana family and Papeiha. Families developed and grew in number contributing to the mana of Tinomana since the increase in family numbers strengthens the mana of the chief. Buck (1958) agrees in saying as the family grew, the senior family head became chief of increasing power. As the Tinomana family increased, the mana of Tinomana increased demonstrating the interconnection between chief and family. When a family is strong, the chief is strong and when the chief is strong, family is strong. According to Hoskins and Jones (2017), whānau is the core social unit rather than the individual. I agree and furthermore maintain that the family is the chief, just as the chief is the family. This support's Buck's view that the stronger the family, the more powerful the chief. A chief is insignificant without the family. 
Papeiha and Te vaerua o te rangi had children together. One son, Isaia, was educated in England by the London Missionary Society. Isaia returned to Rarotonga where he was the minister for the Arorangi Church following in the footsteps of his father. Isaia married Louisa Agostini who was the daughter of a Corsican trader Joseph Agostini and his wife Ua'a, the daughter of the Mangaian chief Mura'ai. One of their children was a daughter named Rangita'i. Rangita'i married Stanley Heather the son of an Englishman, Dennett Hersee Heather, and a Waikato woman of the hāpu Ngāti Tamainupō, Unaiki Te Watarauhi. Rangita'i and Stanley had one son whom they named Enuarurutini Stanley Heather demonstrating the significance of the names of our tupuna to our family. Naming helps to maintain a sense of identity, and it connects us to land and heritage (Cuthers, 2018). Our tupuna is as significant to the family dead as they are alive. Enuarurutini married Te Upoko Exham, and they had fifteen children one of these being my mother's paternal grandmother, Tutevera Heather.

During my family's recent trip to Rarotonga, we stayed at the home of my maternal grandfather William in the village of Arorangi in the Pua'ikura district. This particular land was set aside for William by his mother, Tutevera. Tutevera had allocated pieces of land for all her children so that her family were bound to each other by the land, her family land. Tutevera remains in the land and is one with the land, as is her family, my family. When discussing land tenure in Vanuatu, Larmour and Alatoa (1984) say the tribe is its land, just as the tribe is its ancestors. I agree that we are all bound together by the land. When I stay on the land, the family surrounds me. I am walking on and with my family. Valaskakis (2005) agrees saying, "we are all connected through our feet, through the land to our ancestors" (p. 105). My family story is on this land and is the land, and it teaches me. These particular stories I refer to are stories born of the relationship of my family to the surrounding land. "Knowledge is held in the relationships and connections formed with the environment that surrounds us" (Wilson, 2008, 
p. 87). I agree that knowledge is contained in the land. Furthermore, I believe that the land acts as a conduit for my family to speak and tell our story throughout the generations.

The interconnection between the principles of chief, family and land in the 'mana model' can be further demonstrated in my story. During our time in Rarotonga, my children and I walked to the Arorangi Cook Island Christian church. Next to the church is the palace of Tinomana called the Au Maru. The church and Au Maru represent the union Tinomana made with Papeiha. It retells the story of Tinomana and Papeiha for us, their descendants, to embrace and understand. Buck (1958) explains how history and social ceremony developed around the chief and his or her family. I came to realise that anything of importance in Pua'ikura gravitates around this location. All funerals, all family gatherings are centred on this land which supports Buck's argument. The relationship between the principles of chief, family and land contribute to the mana of the collective, which becomes a foundation for its members to add to through their achievements (Cuthers, 2018). Understanding mana enhances the mātauranga of self which is a foundation for retrieving further mātauranga. Rama (2003) agrees that if there is no understanding of self, what follows externally will not produce the desired results.

According to Durie (2003) whānau refers to a group of people brought together for a particular purpose. Their particular purpose, even when dead, is to pass on mātauranga to the younger generations to enhance their mana. Understanding family enables understanding of where we fit in the world. Hoskins and Jones (2017) agree and go on to say that whānau is a way to organize the social world. The interactions and experience within the family develop the way in which we view the world. I agree with Hoskins and Jones, and I believe that understanding the family enhances further mătauranga. Furthermore, I reaffirm Durie's belief and say that mātauranga unites the family. 
The location of the Au Maru of Tinomana next to the church demonstrates how the community activities developed around Enuarurutini and Papeiha. Valakaskis (2005) says "our land is our memory. Everything has a story" (p. 123). I agree. The story tells of the family of the land that speaks to me now; I see it, I understand it, I feel it, it is all around me at this place. It is mātauranga. My family are the lecturers, and I am the student. In front of this church are buried many tupuna and family. The majority of the deceased descend from both Enuarurutini and Papeiha and their bodies buried here in front of the church next to Au Maru demonstrates the legacy of these two tupuna who changed the history of Rarotonga. They are together in one space to act as a symbol of unity with the place and chief to retell the family story. However, it is my view that this story needs to be nurtured, maintained, and passed on to keep the land, family and chief significant.

The Tinomana family is vast in number today, and we are not all known to each other. According to Durie (2011), the primary role of the whanau is the transmission of knowledge. In my view, it is an important role. For those of our family living away from Rarotonga, especially those of us born overseas, it can be easy not to maintain the connection to our family and relations. We may lose the mātauranga to keep our tupuna significant. I believe the younger generations, especially if they were born and raised overseas and had never travelled back to the land, may not be told or may forget the stories of the land or who is who within the family and how they connect. Durie (2003) agrees that whānau disempowerment is a commonality among indigenous people. I believe part of the reason is due to globalisation which has taken us away from our ancestral homes. However, Durie (2011) believes that because whānau are more dispersed, they can utilise new technology to lessen the distance between each other. Not only does returning to Rarotonga with my children help to foster mātauranga but these days I also utilize technology in Aotearoa to communicate with some of my family in Rarotonga so that my children can 
continue to cultivate their connectivity to the family. Technology now allows family to transfer mātauranga globally.

There is a monument more significant than any of the other headstones or monuments at the burial ground to commemorate Papeiha. The monument reads "Loving memory of Papeiha Raiatea. He was the first to preach the Christian message in Rarotonga 25 July 1823. Erected by his descendants 25th July 1974". I showed my children this monument and explained that Papeiha is our tupuna. The monument is a symbol of our tupuna, of our family and our land. This reinforces Rangiwai's (2018) previously mentioned view that mātauranga is embedded in our world, located in our whenua, tupuna and whanau. As Enuarurutini was Tinomana, so was each tupuna from him to me. Knowing my connection to Enuarurutini allows me to understand how mātauranga transmits from each tupuna to me, validating the earlier mentioned view on erasing time and space (Spiller and Wolfgramm, 2015). The land, on which my tupuna are buried, now speaks their voice and tells their story. Here my family will always have a voice that no one can ever silence. As Moana Jackson (2011) states "stories are knowledge, and knowledge is literature" (p. 71). I agree with this view; there is mātauranga of my family embedded in this land.

nuarurutini and Papeiha both made their mark on history. There I stood at their church with my eldest son Kelekolio, my daughter Antonia and my youngest son Eli. We stood on land that connects Tinomana to his family; us. I am the Tinomana family, just as the Tinomana family is the land and just as the Tinomana family is Tinomana. I understand that the mana created by this interconnection contributes to the mana that I embody (Cuthers, 2018). Here, in Arorangi in front of Au Maru and the church, is the story of many of my tupuna who understood the relationship between the chief, family and land. Here in Arorangi whakapapa has enabled a connection with tupuna throughout the generations and examined their views and communicated them through this literature. 
Furthermore, this article has enabled a deeper understanding of the significance of my tupuna to knowledge production and my mana.

Indeed, the mana model enhances mâtauranga. The stories of our chiefs, land and family need to be retold and maintained to protect and enhance our mātauranga and also demonstrate the significance of our tupuna. Whakapapa is a system of knowledge that allows one to access mâtauranga through the eyes of treasured tupuna throughout the generations. Furthermore, land contributes to our identities by speaking our family story. The foundation of our mătauranga lies within our families and is contained in the land and voiced by the land throughout time. Through the mana model, one can identify and access mātauranga held in the Māori and indigenous world. Once we reclaim our mātauranga, we can further understand how significant we are.

\section{Model of practice in action}

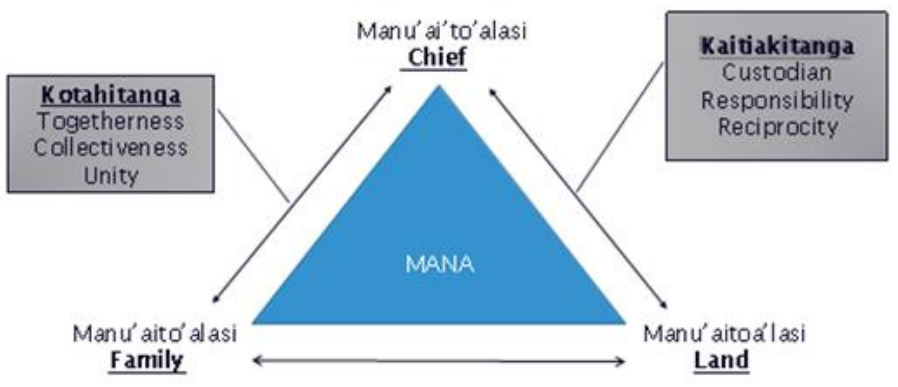

My model of practice, 'the mana model', is underpinned by the principles of chief, family and land (Cuthers, 2018). I will utilize autoethnography, by discussing my stepfather who is the chief for his family and holds the title of Manu'aito'alasi, to demonstrate the mana model. I will describe how the underlying principles are interdependent and I will argue that mana is a 
result of these principles, chief, land and family, functioning as one.

According to Rangiwai (2018), to access knowledge, we need to seek out our stories. I will retell the following story, which I was told as a child, to explain the mana model. A Tongan man by the name of Folola settled in the village of Mulivai Safata in Samoa. He fought wars for the high chief of the land and, as a result, he carried many wounds translated as 'manu'aito'alasi'. The high chief rewarded Folola for his service to him and his land by making Folola his talking chief or tulafale and gave him the title Manu'aito'alasi. Along with this title land was bestowed on him by the high chief.

According to Wilson (2008) the word indigenous means "born of that environment" (p.88). The title Manu'aito'alasi was born of the relationship of Folola to the land. Folola's achievements on the land and guardianship of it gave birth to the title Manu'aito'alasi which has become a symbol of the mana of Folola. Tomoniko (2014) asserts that chiefs are part of the landscape. The title Manu'aito'alasi and the mana it represents remain long after Folola has passed. The title has firmly embedded Folola into the story of the land. Jackson (2011) says that "stories are knowledge" (p. 71). The story of Manu'aito'alasi and the mana it holds remains as knowledge for his family.

Manu'aito'alasi is synonymous not only with the land but also with the family of the land. Tomoniko (2014) agrees, explaining that the chief title is connected to the land and has leadership over the land and everything in it. However, Manu'aito'alasi has a responsibility to his family and land just as they have a responsibility to him. There needs to be a reciprocal relationship for the community to function effectively. The chief is the primary decision-maker in matters regarding the welfare of the family (Palenapa, 1993). However, the chief cannot make decisions for his or her family or land without consulting the family. This fosters collectivism. The title belongs to the particular family and, as Palenapa (1993) explains, the title is the property of the family. He furthermore points out that 
a chief cannot claim influence or authority outside their family. Therefore, the chief relies on the family. A chief is not a chief if he or she has no family or land. The family and land contribute to the mana of the chief (Cuthers, 2018). Larmour and Alatoa (1984) reaffirm this saying the tribe is its land, just as the tribe is its ancestors. The Manu'aito'alasi family is its land, just as the land is Manu'aito'alasi. The chief's leadership binds the family and land together.

My stepfather Kelekolio Tovia descends from Folola and is connected to him and his land by their gafa or whakapapa. Wendt states, "we are real and connected in gafa or whakapapa of the bone, le ivi, te iwi, which is the whenua, the placenta, the land, the elelele" (Sharrad, 2003, p. 94). Kelekolio was appointed Manu'aito'alasi by his family to be the voice on their land. He is chief only because his family gave him this role; he cannot exist without his family or his land. As Manu'aito'alasi he has primary guardianship over the family and the land and speaks for the family and the land. The voice of the family of the land flows through Manu'aito'alasi, reaffirming that chief, family and land are one.

In conclusion, understanding the principles of chief, land and family allows an understanding of their interconnectedness. Chiefs are responsible to and need the family and the land, just as the family and mana of the land rely on the chief. The chief symbolizes the mana of the family. Their collective story is embedded in the land. These principles, effectively working together in reciprocal relationships, promote unity and achieve collective mana. 


\section{Bibliography}

Buck, P. (1958). Vikings of the sunrise. Christchurch, New Zealand: Whitcombe $\&$ Tombs Ltd.

Crocombe, R., \& Holmes, R. (2014). Pre-European Southern Cook Islands Māori Society (Vol. 2). Auckland, New Zealand: Ross Holmes.

Cuthers, W. (2018). Reclaiming Identity. Te Kaharoa, 11(1). https://doi.org/10.24135/tekaharoa.v11i1.219

Cuthers, W. (2018). The Mana Model. Te Kaharoa, 11(1). https://doi.org/10.24135/tekaharoa.v11i1.220

Durie, M. (2003). Ngā kāhui pou: Launching Mãori futures. Wellington, Aotearoa New Zealand: Huia Publishers.

Durie, M. (2011). Ngā tini whetū: Navigating Mãori futures. Wellington, Aotearoa New Zealand: Huia Publishers.

Dagar, R. (2014). Gender, identity and violence: Female deselection in India. New Delhi, India: Routledge.

Gear, A. (2018). Power understanding: Helping students explore, question, and transform their thinking about themselves and the world around them. Ontario, Canada: Pembroke Publishers.

Gilbert, J. (2016). Indigenous peoples land rights under international law: From victors to actors. Leiden, Netherlands: Printforce.

Gilson, R. (1980). The Cook Islands 1820-1950. New Zealand: Victoria University Press.

Hau'ofa, E. (2000). Pasts to remember. In R. Borofsky (Eds.), Remembrance of Pacific pasts. Hawai'i, HI: University of Hawai'i Publishers.

Hoskins, T., \& Jones, A. (2017). Critical conversations in kaupapa Māori. Wellington, Aotearoa New Zealand: Huia Publishers.

Jackson, M. (2011, 5-6 May). Hui reflections: Research and consolations of bravery. Kei tua o te pae hui proceedings, pp 71-78. Retrieved

from: http://www.nzcer.org.nz/system/files/Hui_Procedings_v3_Web_ 1_2.pdf

Jonassen, J. (2003). Cook Island Māori names ingoa. Suva, Fiji: Institute of Pacific Studies, The University of the South Pacific.

Larmour, P., \& Alatoa, H. (1984). Land tenure in Vanuatu. Suva, Fiji: Institute of Pacific Studies, University of the South Pacific and University of the South Pacific Extension Centre.

Meleisea, M. (1987). The making of modern Samoa: Traditional authority and colonial administration in the modern history of Western Samoa. Suva, Fiji: Institute of Pacific Studies of the University of the South Pacific.

Palenapa, L.F. (1993). A study of the place of Samoan culture (Fa'asamoa) in two New Zealand churches (Master's thesis, the University of Canterbury, Christchurch, New Zealand). Retrieved from 
https://ir.canterbury.ac.nz/bitstream/handle/10092/8127/pale napa_thesis.pdf; sequence $=1$

Rama, S. (2003). The art of joyful living. Pennsylvania, PA: Himalayan Institute Press.

Rangiwai, B. (2018). "Stories are knowledge, and knowledge is literature": Viewing and re-viewing sites/cites of mātauranga Māori as an alternative to traditional Western literature reviews. Te Kaharoa, 11(1). https://doi.org/10.24135/tekaharoa.v11i1.229

Page Break

Rangiwai, B. (2018). Hereditary entanglement - the significance of whakapapa and genealogical locatedness in Māori research: A researcher's personal experience. Te Kaharoa, 11(1). https:// doi.org/10.24135/tekaharoa.v11i1.177

Sharrad, P. (2003). Albert Wendt and Pacific literature: Circling the void. Manchester, United Kingdom: Manchester University Press.

Spiller, C., \& Wolfgramm, R. (2015). Indigenous spiritualities at work: Transforming the spirit of enterprise. Charlotte, NC: Information Age Publishing.

Swidler, N., Dongoske, K. E., Anyon, R., \& Downer, A. S. (1997). Native Americans and archaeologists: Stepping stones to common ground. Walnut Creek, CA: AltaMira Press.

Tomoniko, F. (2014). The changing roles of the Polynesian paramount chief (Doctoral thesis, the University of Auckland, Auckland, New Zealand). Retrieved from http:/ / apo.org.au/system/files/110836/apo-nid110836440931.pdf

Wilson, S. (2008). Research is ceremony: Indigenous research methods. Manitoba, Canada: Fernwood Publishing.

Williams, J. (1842). A narrative of missionary enterprises in the South Sea Islands: with remarks upon the natural history of the islands, origin languages, traditions and usages of the inhabitants. London, England: John Snow.

Valaskakis, G. G. (2005). Indian country: Essays on contemporary native culture. Ontario, Canada: Wilfried Laurier University Press. 